\title{
Targeted treatments for cervical cancer: a review
}

This article was published in the following Dove Press journal:

OncoTargets and Therapy

I November 2012

Number of times this article has been viewed

Oscar Peralta-Zaragoza'

Víctor Hugo Bermúdez-

Morales'

Carlos Pérez-Plasencia ${ }^{2,3}$

Jonathan Salazar-León'

Claudia Gómez-Cerón'

Vicente Madrid-Marina'

'Direction of Chronic Infections and Cancer, Research Center in Infection Diseases, National Institute of Public Health, Cuernavaca, Morelos, México; ${ }^{2}$ Oncogenomics Laboratory, National Cancer Institute of Mexico, Tlalpan, México; ${ }^{3}$ Biomedicine Unit, FESIztacala UNAM, México City, México
Correspondence: Oscar Peralta-Zaragoza Dirección de Infecciones Crónicas y Cáncer, Centro de Investigación Sobre Enfermedades Infecciosas, Instituto Nacional de Salud Pública, Avenida Universidad No 655, Cerrada los Pinos y Caminera, Colonia Santa María Ahuacatitlán, México 62100

Tel +52 7773292886

Fax +52 7773175485

Email operalta@correo.insp.mx
Abstract: Cervical cancer is the second most common cause of cancer death in women worldwide and the development of new diagnosis, prognostic, and treatment strategies merits special attention. Although surgery and chemoradiotherapy can cure $80 \%-95 \%$ of women with early stage cancer, the recurrent and metastatic disease remains a major cause of cancer death. Many efforts have been made to design new drugs and develop gene therapies to treat cervical cancer. In recent decades, research on treatment strategies has proposed several options, including the role of HPV E6 and E7 oncogenes, which are retained and expressed in most cervical cancers and whose respective oncoproteins are critical to the induction and maintenance of the malignant phenotype. Other efforts have been focused on antitumor immunotherapy strategies. It is known that during the development of cervical cancer, a cascade of abnormal events is induced, including disruption of cellular cycle control, perturbation of antitumor immune response, alteration of gene expression, and deregulation of microRNA expression. Thus, in this review article we discuss potential targets for the treatment of cervical cancer associated with HPV infection, with special attention to immunotherapy approaches, clinical trials, siRNA molecules, and their implications as gene therapy strategies against cervical cancer development.

Keywords: cervical cancer, clinical trials, gene therapy, HPV E6 and E7 oncogenes, siRNAs

\section{Introduction}

Approximately, 500,000 new cases of cervical cancer are diagnosed each year, with 280,000 deaths worldwide, making cervical cancer the second most common malignancy affecting women worldwide. The highest incidences occur in the developing world, where in most countries, cervical cancer is the leading cause of cancer mortality in women. ${ }^{1}$ Clinical, epidemiological, and molecular data associate highrisk HPV infection with cervical cancer development. ${ }^{2}$ The most common worldwide HPV genotypes in patients with invasive cervical cancer are 16, 18, 31, 33, 35, 45, 52, and 58. These findings are relevant for assessing the cross-protective effects of current vaccines, and for the formulation of recommendations for the use of secondgeneration polyvalent HPV vaccines. ${ }^{3}$ The time-specific expression of viral oncogenes enables HPV to integrate into the cellular genome during the division of basal cells and the differentiation of basal epithelium to stratified epithelium. When viral DNA is inside the nucleus but not bound to host DNA, it is in the episomal conformation, which is characteristic of low-grade squamous intraepithelial lesions. However, when HPV DNA binds to host cellular DNA, it is in the integrate conformation, which is found in high-grade squamous intraepithelial lesions and invasive carcinomas. ${ }^{4}$ An early event in HPV-associated carcinogenesis during HPV DNA integration is the 
global perturbation of cellular gene expression by E6 and E7 oncoproteins. In addition, several important interactions of E6 and $\mathrm{E} 7$ oncoproteins with cellular proteins such as AP-1, Bak, c-myc, Epoc-1, E6BP/ERC55, hAda3, IGFBP-3, Mi2, MPP2, NuMA, PDZ, pRb, p2 $1^{\text {wafl/cip1 }}$, p27 $7^{\text {kip1 }}$, p53, p300/CBP, p600, TBP, Tyk2, and hTERT have been reported. ${ }^{5,6}$ Thus, E6 and E7 together exert their effects on cell cycle control, independent cell growth regulation, resistance to apoptosis, immune response escape, and angiogenesis-associated processes; in combination, these HPV oncoproteins efficiently immortalize and transform human keratinocytes for the malignant phenotype.

Research advances in the understanding of the molecular biology of HPV-related tumors have identified molecular targets for therapy such as antigen tumors, growth factor receptors, signaling transduction pathways, and angiogenesis factors. For instance, molecular-targeted drugs tested in clinical trials may inhibit tumor progression and increase apoptosis, resulting in tumor response or stabilization, and immunotherapy strategies could be employed for the control of HPV-associated cervical lesions. Although the commercially available preventive HPV vaccines are highly efficient in preventing HPV infection, they do not have therapeutic effects against established HPV-associated lesions. Since T-cellmediated immunity is highly relevant for treating established HPV infection, therapeutic HPV vaccines should aim to generate potent T-cell-mediated immune responses against antigen tumors and/or HPV E6 and E7 oncoproteins. DNA vaccines represent a promising approach for antigen-specific T-cell-mediated immunotherapy against HPV infection. ${ }^{7}$ Since the toxicity profile and effectiveness of immunotherapy differ from what is observed with classic chemotherapy, these new approaches have enormous therapeutic potential for clinical application in the treatment of HPV-associated cervical cancer, reducing morbidity, mortality, and improving quality of life. Consequently, these immunotherapy approaches are currently considered in clinical protocols. ${ }^{8}$

On the other hand, the ability to selectively silence mammalian gene expression using siRNAs offers new and exciting possibilities in mammalian cell biology and pathology. Due to the sequence-specific interaction of siRNA targeting mRNA, siRNA technology could feasibly be utilized in the development and application of therapeutic strategies. ${ }^{9}$ Therefore, in this review we discuss potential targets for the treatment of HPV-associated cervical cancer, with special attention to immunotherapy approaches, clinical trials, siRNA molecules, and their applications as gene therapy strategies against cervical cancer development.

\section{Choosing targets for immunotherapy and gene therapy against HPV}

The high prevalence of HPV-associated lesions and malignancies worldwide means that there is a pressing need to develop therapeutic vaccines against cervical cancer. Choosing adequate molecular targets is crucial for successful therapy. Several strategies of HPV therapeutic vaccines have been evaluated to reverse the effect of immunosuppression in the tumor microenvironment, including inhibition of HPV oncoproteins, activation of the host specific immune response against HPV antigens by costimulatory molecule expression, and administration of Th1 cytokines to activate the T-cell-mediated immune response. ${ }^{10,11}$ However, HPVs have developed different strategies to escape immune control and to establish a persistent infection and remain restricted to the affected epithelium. ${ }^{10,11}$ In order to combat HPV's immune system escape mechanisms, innovative therapies have been developed to activate the immune response to control HPV infection and prevent or treat cervical cancer. Most therapeutic vaccines that have been tested in preclinical and clinical trials are focused on interacting with antigen-presenting cells (APCs) to stimulate cytokine production and T-cell activation. Therapeutic vaccines have also been developed to generate antigen-specific CD4+ and CD8+ T-cells. ${ }^{12}$ HPV E6 and E7 oncoproteins are excellent candidates for HPV therapeutic vaccination strategies, although immunization against them would circumvent some common cancer-vaccine-associated problems such as immune tolerance. On the other hand, HPV E1 and E2 proteins have been reported in animal models and in humans to induce a T-cell response in patients with persistent cervical neoplasia. ${ }^{13,14}$ Table 1 describes the features of these HPV therapeutic vaccines.

\section{Immunomodulatory agents}

Immunomodulatory agents represent another important innovative cancer therapy. Chemotherapeutic drugs such as cyclophosphamide, doxorubicin, and paclitaxel are reported to have apoptotic and immunomodulatory activities and appear to be suitable for chemoimmunotherapy. ${ }^{15,16}$ Recently, some reports have established that tumor cells treated with doxorubicin can acquire the capacity to elicit tumor-specific immune responses when inoculated in syngeneic mice. Such immune responses were found to efficiently protect mice against subsequent rechallenges with live cells, resulting in long-term vaccination. ${ }^{17}$ Since then, great efforts have been dedicated to the elucidation of the cellular mechanisms involved in immunogenic cell death 
Table I Advantages and disadvantages of HPV therapeutic vaccines

\begin{tabular}{|c|c|c|}
\hline Vaccine approach & Advantages & Disadvantages \\
\hline Viral vector-based & $\begin{array}{l}\text { - High immunogenicity } \\
\text { - Wide variety of vectors available } \\
\text { - Can facilitate intracellular antigen spreading } \\
\text { - Different immunological properties of viruses }\end{array}$ & $\begin{array}{l}\text { - Risk of toxicity in using live viruses } \\
\text { - Potential pre-existing immunity may inhibit repeated } \\
\text { administration } \\
\text { - Possible dominance of immune response to viral vector } \\
\text { rather than HPV antigen }\end{array}$ \\
\hline Bacterial vector-based & $\begin{array}{l}\text { - High immunogenicity } \\
\text { - Can deliver either engineered plasmids or HPV tumor } \\
\text { proteins to APCs } \\
\text { - Wide variety of vectors available }\end{array}$ & $\begin{array}{l}\text { - Risk of toxicity in using live bacteria } \\
\text { - Potential pre-existing immunity } \\
\text { - Inhibited repeat immunization }\end{array}$ \\
\hline Peptide-based & $\begin{array}{l}\text { - Easy to produce, stable, safe } \\
\text { - Can combine multiple epitopes } \\
\text { - Can engineer peptides for enhanced MHC binding }\end{array}$ & $\begin{array}{l}\text { - Low immunogenicity } \\
\text { - Epitopes must be determined } \\
\text { - HLA-restriction } \\
\text { - Difficult to have one-fits-all peptide }\end{array}$ \\
\hline Protein-based & $\begin{array}{l}\text { - Stable, safe, easy to produce } \\
\text { - No HLA restriction } \\
\text { - Multiple known adjuvants }\end{array}$ & $\begin{array}{l}\text { - Low immunogenicity; requires adjuvant } \\
\text { - Usually better induction of antibody response than CTL } \\
\text { response }\end{array}$ \\
\hline DNA-based & $\begin{array}{l}\text { - Safe, easy to produce, stable for storage and transportation } \\
\text { - Capacity for repeated administration } \\
\text { - Easy to prepare at high purity } \\
\text { - Several delivery methods possible } \\
\text { - Sustained expression of antigen on MHC-peptide complex } \\
\text { - Can be engineered to add targeting and/or co-stimulatory } \\
\text { genes }\end{array}$ & $\begin{array}{l}\text { - No intercellular spreading immunogenicity } \\
\text { - Risk of integration into genome or cellular } \\
\text { transformation }\end{array}$ \\
\hline RNA-based & $\begin{array}{l}\text { - Non-infectious, no risk of genomic integration or cellular } \\
\text { transformation } \\
\text { - Transient } \\
\text { - Can administer multiple times } \\
\text { - Enhanced antigen expression } \\
\text { - Multiple vectors are available }\end{array}$ & $\begin{array}{l}\text { - Unstable, difficulty in long-term storage } \\
\text { - Labor intensive preparation } \\
\text { - Difficult to prepare large amounts } \\
\text { - No intercellular spreading }\end{array}$ \\
\hline Dendritic cell-based & $\begin{array}{l}\text { - High immunogenicity; uses the most potent APCs } \\
\text { - Multiple methods available to load antigen } \\
\text { - Efficient antigen presentation } \\
\text { - Potency can be enhanced by gene transduction or } \\
\text { cytokine treatment }\end{array}$ & $\begin{array}{l}\text { - Labor intensive, expensive, ex vivo, individualized cell } \\
\text { processing } \\
\text { - Variable quality control and a lack of agreed standards } \\
\text { for quality of vaccines } \\
\text { - Difficult to produce on a large scale } \\
\text { - DCs do not necessarily home to lymph nodes }\end{array}$ \\
\hline Tumor cell-based & $\begin{array}{l}\text { - Useful if tumor antigen unknown } \\
\text { - Likely to express tumor antigens } \\
\text { - Potency can be enhanced by cytokine treatment }\end{array}$ & $\begin{array}{l}\text { - Safety concerns about injecting tumor cells into patients } \\
\text { - Labor intensive as it is individualized } \\
\text { - Costly, difficult to produce on a large scale } \\
\text { - Requires availability of tumor cell lines or autologous } \\
\text { tumor cells }\end{array}$ \\
\hline
\end{tabular}

(ICD) to identify the molecular pathways in dying cells. Such pathways include: (a) endoplasmic reticulum (ER) stresselicited, caspase-dependent pre-apoptotic co-exposure or the ER chaperones calreticulin and ERp57 on the outer leaflet of the plasma membrane; ${ }^{18}$ (b) autophagy-dependent pre-apoptotic secretion of ATP; ${ }^{19}$ (c) post-apoptotic release of the non-histone chromatin binding protein HMGB $1 ; 20$ and (d) cell surface exposure or release of HSP70 and HSP90. ${ }^{21}$ Thus, ICD can be induced in patients with HPV-associated cervical lesions treated with doxorubicin.

On the other hand, imiquimod and gemcitabine (GEM) are immunomodulatory agents recently used for cervical cancer treatment. The specific mechanism of action through which imiquimod and its analogs activate the immune system is still under investigation. Nevertheless, it is known that imiquimod activates immune cells through TLR-7 and induces secretion of interferon-alpha (IFN-alpha), IL-6, and TNF-alpha. ${ }^{22,23}$ There is evidence that imiquimod, when applied to skin, can produce activation of Langerhans cells, which subsequently migrate to local lymph nodes to activate the adaptive immune response. In a randomized, controlled trial of vulva intraepithelial neoplasia treated with imiquimod applied twice weekly for 16 weeks, a $>25 \%$ reduction in lesion size was observed after 20 weeks in $81 \%$ of patients 
compared with none in the placebo group. ${ }^{24}$ Imiquimod has also been used in combination with vaccination with HPV E6, E7, and L1 in Phase I/II trials in vulva intraepithelial neoplasia. The treatment induced up to a $79 \%$ reduction in lesion size and was associated with an increment in local infiltration of CD4+ and CD8+ T-cells. ${ }^{25}$ The combination of imiquimod with E7 DNA vaccination enhanced antitumor immunity and increased the number of NK1.1+ cells in the tumor microenvironment. ${ }^{26}$ GEM, a pyrimidine nucleoside anti-metabolite, is a relatively new cytostatic agent with potent antitumor activity demonstrated in a wide spectrum of in vitro and in vivo animal tumor models and for which efficacy has been confirmed in a variety of clinical settings. ${ }^{27}$ GEM has also been shown to have immunomodulatory properties. GEM has been used in combination with immunotherapy and is able to induce tumor necrosis/ apoptosis without adversely affecting T-cell function. In addition to its pro-apoptotic effects, GEM selectively promotes the T-cell-mediated immune response over the humoral immune response by selectively inhibiting B-cell proliferation, decreasing memory T-cells, and promoting the activation of naïve T-cells and function of CD8+ T-cells. ${ }^{28}$ Pre-treatment with GEM can enhance the immunogenicity of tumors by promoting adaptive immune responses.

\section{Cytokines increase the immune response to cervical cancer treatment}

The cytokines have antitumor effects because they induce the activation of the immune system and have immunostimulatory properties, which have been used in immunotherapy approaches to cancer treatment. In addition, these molecules interrupt the pathways that contribute to the uncontrolled growth of cancer cells and prevent cancer from metastasizing to other organs. ${ }^{29}$ Cytokines that have been evaluated in several preclinical and clinical trials for cervical cancer immunotherapy are IL-2, IL-12, granulocyte-macrophage colony-stimulating factor (GM-CSF), and IFN-alpha. ${ }^{30}$ Since the systemic application of cytokines is not possible for extended periods of time in patients due to numerous toxic side effects, a new approach in cancer gene therapy utilizes cytokine genes. Furthermore, costimulators are required to generate a cytotoxic T-lymphocyte (CTL) response. Treatment with GM-CSF-expressing vector enhances the effects of cottontail rabbit papillomavirus (CRPV) E6 vaccination, increasing tumor regression frequency and the probability of rabbits remaining disease-free after CRPV exposure. ${ }^{31}$ IL-12 is a potent immunostimulatory cytokine that exerts antitumor effects in several animal models. ${ }^{32}$
The broad antitumor activity of IL-12 is related to its ability to induce Th1 cytokine-type response and to activate NK cells, NK T-cells, CTL, and APCs. ${ }^{33}$ IL-12 is also an anti-angiogenic agent that can antagonize pro-angiogenic signals during tumor development. ${ }^{33}$ IL-12 as a treatment for cervical cancer has been used with naked DNA vaccine, ${ }^{34}$ viral gene therapy (adenovirus), ex vivo gene therapy, and in combination with E6 and E7 antigens, ${ }^{35} \mathrm{CM}-\mathrm{CSF},{ }^{36} \mathrm{IL}-2$ co-stimulatory receptors (B7), and GEM. Thus, IL-12 is one of the most effective and promising cytokines used in preclinical and clinical trials for cervical cancer therapies.

\section{Live vector-based vaccines}

The live vector-based vaccines are highly immunogenic with minimal toxicity, and can be used for the delivery of antigen HPV E6 and E7 to dendritic cells (DCs). These vaccines have numerous advantages, including the possibility of choosing a desirable vector from a wide range of vectors to deliver antigens, can be engineered for a desired effect, and are classified in bacterial and viral vectors, which have been evaluated as tools for HPV therapeutic vaccine development. ${ }^{13}$ Moreover, replication within host cells of live vectors facilitates intracellular spread of antigens and can enable antigenic spread from cell to cell. This strategy is capable of stimulating antigen expression through major histocompatibility complex (MHC) class I to CD8+ T-cells and MHC class II to CD4+ T-cells. The production of neutralizing antibodies as well as the possibility of preexisting vector-specific immunity in the host during vaccination could reduce the potency of repeated immunizations. Eliminating these activities might improve the efficacy of live vectorbased vaccines. ${ }^{37}$

Attenuated bacterial vector-based vaccines have been explored in HPV therapeutic vaccines, including: Listeria monocytogenes, Lactobacillus lactis, Lactobacillus plantarum, Salmonella enterica, and Bacillus CalmetteGuérin. ${ }^{38}$ L. monocytogenes is the bacterial vector that has generated the most interest, since it has the ability to replicate in the cytosol of APCs and infects monocytes and macrophages. This feature allows peptide antigens derived from $L$. monocytogenes to be processed and presented via both MHC class I/II pathways, in potent CD8+ and CD4+ T-cell-mediated immune responses. Moreover, the sensitivity of L. monocytogenes to antibiotics means the vector can be easily killed if the patient shows severe adverse effects. The L. monocytogenes-based vaccine potency can be further enhanced by means of encoding recombinant proteins composed of HPV E6 and E7 antigens fused to 
immunostimulatory molecules. In preclinical trials it was shown that L. monocytogenes-based vaccines when used against E7 can induce the regression of solid implanted tumors in transgenic mice with tissue-specific expression of HPV16 E6 and E7 oncoproteins and overcome central tolerance by expanding low avidity CD8+ T-cells specific for E7. ${ }^{39}$ In regard to intravaginal immunization with live attenuated $S$. enterica serovar Typhimurium expressing HPV16 antigens induce transient inflammatory responses in the genital mucosa and confer protection against subcutaneously implanted HPV16 tumors. S. enterica has yet to enter clinical trials like the HPV therapeutic vaccine, and hence there is potential for bacterial vectors to not only serve as vaccine vectors but possibly have cancer immunotherapeutic properties as well. ${ }^{40}$ Nevertheless, it is necessary to analyze the immunogenicity of the vector and eliminate vector-associated toxicity for further bacterial vector-based therapeutic vaccine development.

Viral vector-based vaccines are an attractive option for HPV therapy, because they have high immunogenicity and extremely efficient infection rates and expression of encoded antigen in the infected cells. Several preclinical studies show the efficacy of live viral vectors, for example: vaccinia virus, adenoviruses, vesicular stomatitis viruses, alphaviruses, adeno-associated virus, and fowlpox viruses. ${ }^{41-45}$ Vaccinia virus is considered to be particularly promising for antigenspecific immunotherapy due to its high efficiency of infection. In animal models, it has been shown that vaccinia virus constructs encoding HPV E7 generate an E7-specific immune response that enhances antigen presentation to DCs and causes regression of E7-expressing tumors. ${ }^{41}$ The Phase I/II clinical trials have evaluated a recombinant vaccinia vector encoding an HPV16/18 E6 and E7 fusion protein, termed TA-HPV. ${ }^{46}$ In this study, the HPV-therapeutic vaccine was evaluated in patients with therapy-unresponsive late-stage cervical cancer; the patients developed HPV18 E7-specific antibodies and HPV-specific CD8+ T-cells, showing that TA-HPV was capable of eliciting an immune response. ${ }^{46}$ Also, in a safety and immunogenicity study in patients with stage $\mathrm{Ib} / \mathrm{II}$ a cervical cancer, the vaccine was well tolerated and HPV-specific CTL response was observed. Furthermore, TA-HPV has been tested with success in patients with other HPV-associated malignancies ${ }^{47}$ Currently, a recombinant vaccinia virus derived from modified vaccinia Ankara encoding E2 protein (MVA-E2) of bovine papillomavirus, has been tested in patients with cervical intraepithelial neoplasia (CIN) and flat condyloma lesions. MVA-E2 can bind to HPV genome and prevent the upregulation of E6 and E7 oncoproteins for the potential control of HPV-associated CIN lesions. This vaccine has already been evaluated in Phase II clinical trials in CIN 2/3 patients, is well-tolerated and also generated a specific CTL response against HPV-transformed cells. ${ }^{48}$ In addition, MVA-E2 vaccine has been probed in a Phase I/II study of men with intraurethral flat condyloma. In this study, patients developed antibodies against MVA-E2 protein over a 4-week period, and had no detectable viral DNA after treatment. Moreover, patients did not show any recurrence of lesions after 1 year of treatment. Therefore, MVA-E2 has demonstrated efficacy in controlling HPVassociated lesions, although all the molecular mechanisms are not known. ${ }^{49}$

\section{HPV peptide and protein-based vaccines}

HPV antigen-specific immunotherapy has emerged as an attractive approach for the treatment of cervical cancer with the potential to control metastases without damaging normal cells. Immunotherapy using synthetic long peptide vaccines derived from HPV16 E6 and E7 antigens has produced significant clinical responses in patients with precancerous lesions for gynecological malignancies. ${ }^{50}$

Peptide-based vaccines involve the direct administration of peptides derived from HPV antigens for uptake by DCs, and presented in association with the MHC class I/II molecules. The peptide-based vaccines are easy to produce, stable, and safe but have low immunogenicity. The polymorphic nature of HLA molecules in genetically diverse populations makes it difficult to identify an immunogenic epitope which would cover all individuals. Thus, the production of an effective vaccine in a variety of patients with different HLA haplotypes is impractical for large-scale vaccination treatments. This can be overcome through the use of overlapping long peptides that contain several HPV E6 and E7 epitopes. ${ }^{51}$ Therefore, the development of peptide-based vaccines could be made possible by the identification of several MHC-restricted CD4+ and CD8+ T-cell epitopes of HPV early proteins in murine and human models. Another disadvantage of these vaccines is the poor immunogenicity where a possibility is the use of adjuvant treatment to enhance vaccine potency. ${ }^{52}$ Other possibilities to potentiate peptide-based vaccines are the implementation of intranasal route of administration, the link of peptides to lipids, and the enhancement of epitopes to prevent peptide degradation. Some of the most employed adjuvants in peptide-based vaccines on preclinical trials are: 4-1BB ligand, mutant cholera toxin, and CpG-ODN, which mimic bacterial danger signals for TLR-9.53,54 Therapeutic vaccination with HPV E6 and E7 long peptides has been 
shown to result in the control of both established virusinduced lesions and lately infected sites. Thus, several peptide-based vaccines have been found to be safe and well tolerated in preclinical trials. ${ }^{55}$

Protein-based vaccines against HPV-associated cervical cancer are an excellent strategy, because they are safe and easy to produce. Protein antigens may be processed and presented on the surface of DCs and contain all possible HLA epitopes of an antigen. However, these vaccines present low immunogenicity, and as a result, adjuvant and fusion protein strategies are often used to enhance vaccine potency. A limitation of protein-based vaccines is that proteins may elicit better antibody responses than CTL responses and APCs might only occasionally encounter and engulf an injected protein for MHC class I presentation. The use of adjuvant, such as the liposome-polycation-DNA or the saponin-based adjuvant ISCOMATRIX and HPV E6 and E7 fusion proteins can improve CTL responses. ${ }^{55,56} \mathrm{HPV} 16$ E7 protein fusion with bacterial proteins such as the Bordetella pertussis adenylate cyclase, the translocation domain of Pseudomonas aeruginosa exotoxin A, or the Mycobacteriaderived HSP proteins, induce E7-specific CTL responses and inhibit angiogenesis in tumors. ${ }^{57}$

\section{DNA- and RNA-based vaccines}

Once the DNA vaccines are taken up by DCs, the efficiency of antigen expression, processing, and presentation by DCs significantly impacts the ability of DCs to present the antigenic peptide to prime the antigen-specific T-cells. Several strategies have been developed to improve the antigen expression, processing, and presentation of DCs, including (a) codon optimization and demethylating agents to improve antigen expression, (b) intracellular-targeting strategies to improve MHC I/II presentation of antigen in DCs, (c) a strategy to enhance the expression of MHC class I/II molecules, and (d) MHC class I single-chain trimer (SCT) technology to bypass antigen processing and presentation in DCs.

Codon optimization refers to the modification of antigenic gene sequences by replacing codons that are rarely recognized by cellular protein synthesis machinery with codons that are more commonly recognized. For example, mice immunized with codon-optimized HPV16 E6 DNA were shown to generate enhanced antigen-specific CD8+ T-cell immune responses. ${ }^{58}$ Another strategy to improve the gene expression of the encoded HPV antigen is the employment of demethylating agents. It has been demonstrated that demethylating agent 5-aza-2'-deoxycytidine co-delivered with an E7 DNA vaccine can overcome gene silencing by methylation of $\mathrm{CpG}$ islands in the CMV promoter and thus increase the gene expression levels. ${ }^{59}$ Strategies to enhance the expression of MHC class I/II molecules have also been used to improve therapeutic HPV DNA vaccine potency. It has been shown that co-administration of CIITA DNA, a master regulator of MHC class II expression, with therapeutic HPV DNA vaccines has been shown to enhance antitumor effects and prolong survival in HPV antigenexpressing TC-1 tumor-bearing mice. ${ }^{60}$ DNA vaccines encoding a SCT composed of an HPV16 E6 CTL epitope linked to the beta2-microglobulin and heavy chain of $\mathrm{H}-2 \mathrm{~Kb}$ MHC class I have been shown to enhance the E6-specific CD8+ T-cell responses. ${ }^{61}$

RNA replicons are naked RNA that can replicate in a self-limiting fashion into transfected cells. Therefore, these vaccines could sustain cellular antigen expression and as a result, produce more antigenic protein than conventional naked DNA vaccines. RNA replicons may be derived from alphaviruses, Semilki Forest virus, or Sindbis virus, and can replicate in a wide range of cell types. ${ }^{62,63}$ Many replicons are designed to lack the structural genes, and thus noninfection particles are produced in the host and prevent the formation of neutralizing antibodies. Furthermore, RNA replicons minimize the risk of potential chromosomal integration and cellular transformation associated with DNA vaccines. In addition, the expression of inserted genes in RNA-based vaccines is transient and thereby reduces their effectiveness in stimulating the immune system. RNA replicons have shown promising results in preclinical models; however it is recommended that they be evaluated for efficacy and safety.

\section{Tumor cells-based vaccines}

The use of tumor cells-based vaccines is an interesting strategy, because it is not necessary to clearly identify the tumor antigens. However, tumor antigens associated with HPV are largely known. Manipulation and isolation ex vivo of tumor cells to express immunomodulatory proteins can enhance their immunogenicity in vivo by expressing cytokines such as IL-2, IL-12, and GM-CSF. In a murine model, vaccination with GM-CSF-expressing tumor cells led to an E7-specific CTL response and potent antitumor effects against tumors. Furthermore, vaccination with irradiated HPV E6 and E7-positive tumor cells expressing IL-12 significantly decreased the size of E6 and E7-expressing tumors. ${ }^{64}$ In another preclinical trial, expression in tumors of the ligand of lymphotoxin-beta receptor generated an increased expression of IFN-gamma, IL-1-alpha, MIG, and MIP-2. This result 
increased the frequency of tumor-infiltrating CTLs and eradication of large established tumors. Nevertheless, tumor cell-based vaccines are costly and difficult to produce on a large scale without introducing variations in purity and efficacy, so this strategy has limited scope for HPV vaccine development. $^{37}$

\section{Dendritic cells-based vaccines}

This strategy was designed to enhance T-cell-mediated immunity by loading DCs with HPV antigens ex vivo and delivering in HPV-associated lesions, acting as natural adjuvant. DCs can be prepared ex vivo for various methods including the usage of viral vectors, transfection with DNA or RNA encoding antigen, and pulsation of DCs with antigenic protein, peptide, or tumor cell lysates. Moreover, reintroduction of mature DCs bearing HPV antigens allows for more effective antigen presentation and thus a stronger immune response. Effective loading of tumor antigen into DCs can be achieved through gene delivery to DCs by targeting adenoviral vectors to CD40 with specific antibodies. Intramuscular delivery has been shown to be the most effective method for generating large numbers of E7-specific CD8+ T-cell precursors. ${ }^{37}$ Clinical trials have been developed. For example, in a study of DCs loaded with HPV16 or HPV18 E7 co-administered with IL-2 in HPV16/18+ refractory cervical cancer, patients showed E7-specific CD4+ and CD8+ T-cell responses. ${ }^{65}$ In a case report, subcutaneous injection of HPV18 E7-pulsed DCs in a patient with metastatic cervical cancer led to inhibition of tumor progression, but did not result in complete remission. ${ }^{66}$ The success of DCs-based vaccines has serious limitations; these vaccines cannot be produced at a large scale because they are complicated to produce and expensive. In addition, it is necessary elucidate the most effective delivery route and develop methods to enhance antigen loading.

\section{Gene therapy clinical trials for cervical cancer}

Proper clinical trial design is critical to ensure the scientific validity of research results, the potential benefits to society from the knowledge gained, and the ethics of conducting experimentation on human research participants. Treatment options are limited for women with metastatic or recurrent cervical cancer. Unfortunately, only up to one-third of patients with metastatic and recurrent disease will respond to immunotherapy or drug chemotherapy, and these responses are short-lived, in the order of months. Therefore, gene therapy strategies targeted to HPV products could be employed not only for cervical cancer but also in other tumors where HPV participates as a cancer promoter. Table 2 summarizes systematic information on gene therapy clinical trials worldwide in cervical cancer from 1989 to 2012. The data were compiled from official agency sources such as RAC, GTAC, and the OBA/RAC website. ${ }^{67}$ In many clinical trials, the safety, tolerability, and immunogenicity of HPV E6 and E7 oncogenes are evaluated in combination with immunotherapy and chemotherapeutical drugs. There are several studies still running and recruiting participants. For example, trial US-0928 proposes to study the side effects and the best dose of vaccine therapy, and to evaluate how well it works when given with or without imiquimod when treating patients with CIN 3. Trial US-0984 analyzes the efficacy and safety of different routes of administration of a naked plasmid DNA vaccine in patients with HPV16+ CIN 2/3. Trials UK-0041 and UK-0042 evaluate a live vaccinia virus containing HPV16 and 18 E6/E7 gene construct (TA-HPV) in patients with advanced cervical cancer. Trial BE-0024 is a randomized, double-blind, placebo-controlled, parallelarm study, which aims to assess the safety and efficacy of RO5217790 on histological resolution in patients with highgrade CIN associated with high-risk HPV infection. This study is ongoing, but not recruiting participants. ${ }^{68,69}$

On the other hand, antisense RNA has been employed to block the translation of HPV E6 and E7 mRNA and these works have shown a significant reduction of viral proteins and concordantly, a loss of many features of transformed cells. ${ }^{70}$ These studies were performed in vitro and established the feasibility of targeting viral oncoproteins to reduce the tumor phenotype. As previously stated, the primary effect of viral oncoproteins is the loss of function of cellular proteins p53 and $\mathrm{pRb}$; hence, it seems likely that HPV-associated tumors could be reverted by replacement of functional wild-type p53 and pRb. Nevertheless, tumor resection results have not shown sufficient consistency, due to uncontrolled expression of proteins that may affect the viability of targeted cells.

Although there is limited clinical information about gene therapy in cervical cancer patients, gene therapy could establish the proof of concept; therefore, it could be feasible to use gene therapy in situ. However, the choice of gene target is the most relevant aspect in these kinds of clinical protocols. Clinical trial findings will address broad issues about gene therapy vaccines including efficacy, duration of protection, and the global impact of vaccination on HPVrelated tumors, which likely will have the greatest public health benefit; however, continued screening will still be required after intervention. 
Table 2 Gene therapy clinical trials worldwide on cervical cancer from 1989 to 2012

\begin{tabular}{|c|c|c|c|c|c|c|}
\hline ID trial & Title/Country & $\begin{array}{l}\text { Indication/ } \\
\text { clinical phase }\end{array}$ & $\begin{array}{l}\text { Status/year } \\
\text { approved- } \\
\text { initiated }\end{array}$ & $\begin{array}{l}\text { Gene(s) } \\
\text { transferred }\end{array}$ & $\begin{array}{l}\text { Vector used/ } \\
\text { administration } \\
\text { route }\end{array}$ & $\begin{array}{l}\text { Gene } \\
\text { delivery }\end{array}$ \\
\hline BE-0024 & $\begin{array}{l}\text { A randomized, double-blind, } \\
\text { placebo-controlled, parallel group, } \\
\text { multi-center study of the safety and } \\
\text { response rate of } 3 \text { subcutaneously } \\
\text { administered doses of } 5 \times 10^{7} \text { pfu } \\
\text { RO52 I7790 in patients with high- } \\
\text { grade cervical intraepithelial } \\
\text { neoplasia grade } 2 \text { or } 3 \text { associated } \\
\text { with high-risk HPV infection. Belgium }\end{array}$ & $\begin{array}{l}\text { Cervical intraepithelial } \\
\text { neoplasia. } \\
\text { Phase I }\end{array}$ & $\begin{array}{l}\text { Open } \\
\text { 2009-ND }\end{array}$ & $\begin{array}{l}\text { - delE6 } \\
\text { - delE7 } \\
\text { - IL-2 }\end{array}$ & Vaccinia virus/ND & ND \\
\hline $\mathrm{CH}-0035$ & $\begin{array}{l}\text { Immunotherapy for stage I cervical } \\
\text { carcinoma. Switzerland }\end{array}$ & $\begin{array}{l}\text { Stage I cervical } \\
\text { carcinoma. } \\
\text { Phase I }\end{array}$ & $\begin{array}{l}\text { Closed } \\
1999-2002\end{array}$ & - IL-2 & $\begin{array}{l}\text { Vaccinia virus/ } \\
\text { intramuscular }\end{array}$ & ND \\
\hline $\mathrm{CH}-0036$ & $\begin{array}{l}\text { Immunotherapy for advanced } \\
\text { cervical carcinoma. Switzerland }\end{array}$ & $\begin{array}{l}\text { Advanced cervical } \\
\text { carcinoma. } \\
\text { Phase I }\end{array}$ & $\begin{array}{l}\text { Closed } \\
1999-2002\end{array}$ & - IL-2 & $\begin{array}{l}\text { Vaccinia virus/ } \\
\text { intramuscular }\end{array}$ & ND \\
\hline CN-00IO & $\begin{array}{l}\text { Gendicine intratumoral injection } \\
\text { combined with radiotherapy } \\
\text { for advanced cervical } \\
\text { carcinoma. China }\end{array}$ & $\begin{array}{l}\text { Cervical carcinoma. } \\
\text { Phase III }\end{array}$ & $\begin{array}{l}\text { Open } \\
\text { 2008-ND }\end{array}$ & - $\mathrm{p} 53$ & $\begin{array}{l}\text { Adenovirus/ } \\
\text { intramuscular }\end{array}$ & ND \\
\hline ES-0010 & $\begin{array}{l}\text { A randomized, double-blind, } \\
\text { placebo-controlled, parallel group, } \\
\text { multi-center study on the safety } \\
\text { and response rate of } 3 \\
\text { subcutaneously administered } \\
\text { doses of } 5 \times 10^{7} \text { pfu RO5217790 } \\
\text { in patients with high-grade cervical } \\
\text { intraepithelial neoplasia grade } 2 \\
\text { or } 3 \text { associated with high-risk } \\
\text { HPV infection. Spain }\end{array}$ & $\begin{array}{l}\text { Cervical intraepithelial } \\
\text { neoplasia. } \\
\text { Phase I }\end{array}$ & $\begin{array}{l}\text { Open } \\
\text { 2009-ND }\end{array}$ & $\begin{array}{l}\text { - delE6 } \\
\text { - delE7 } \\
\text { - IL-2 }\end{array}$ & Vaccinia virus/ND & ND \\
\hline FR-0032 & $\begin{array}{l}\text { Phase II trial to assess efficacy of } \\
\text { TG400I (MVA-HPV-IL2) in } \\
\text { patients with grade } 2 / 3 \text { cervical } \\
\text { intra-epithelial neoplasia (CIN 2/3) } \\
\text { linked to HPVI6 infection } \\
\text { (protocol TH400I.07). France }\end{array}$ & $\begin{array}{l}\text { CIN } 2 \text { and } 3 . \\
\text { Phase II }\end{array}$ & $\begin{array}{l}\text { Open } \\
\text { 2004-ND }\end{array}$ & $\begin{array}{l}\text { - IL-2 } \\
\text { - HPVI6 }\end{array}$ & Vaccinia virus/ND & ND \\
\hline MX-000I & $\begin{array}{l}\text { Clinical protocol. A Phase II study: } \\
\text { Efficacy of the gene therapy of the } \\
\text { MVA E2 recombinant virus in the } \\
\text { treatment of precancerous lesions } \\
\text { (NIC I and NIC II) associated with } \\
\text { infection of oncogenic human } \\
\text { papillomavirus. Mexico }\end{array}$ & $\begin{array}{l}\text { Cervical cancer. } \\
\text { Phase II }\end{array}$ & $\begin{array}{l}\text { Open } \\
\text { ND-ND }\end{array}$ & - ND & Adenovirus/ND & ND \\
\hline UK-004I & $\begin{array}{l}\text { Use of a recombinant Vaccinia } \\
\text { vaccine (TA-HPV) to treat cervical } \\
\text { intraepithelial neoplasia III. UK }\end{array}$ & $\begin{array}{l}\text { Cervical intraepithelial } \\
\text { neoplasia III. } \\
\text { Phase I }\end{array}$ & $\begin{array}{l}\text { Open } \\
\text { 1996-ND }\end{array}$ & $\begin{array}{l}\text { - HPV E6 and } \\
\text { E7 oncogenes }\end{array}$ & Poxvirus/ND & ND \\
\hline UK-0042 & $\begin{array}{l}\text { Use of a recombinant Vaccinia } \\
\text { vaccine (TA-HPV) to treat cervical } \\
\text { intraepithelial neoplasia III. UK }\end{array}$ & $\begin{array}{l}\text { Cervical intraepithelial } \\
\text { neoplasia III. } \\
\text { Phase I }\end{array}$ & $\begin{array}{l}\text { Open } \\
\text { I997-ND }\end{array}$ & $\begin{array}{l}\text { - HPV E6 and } \\
\text { E7 oncogenes }\end{array}$ & Poxvirus/ND & ND \\
\hline UK-0046 & $\begin{array}{l}\text { Use of a recombinant Vaccinia } \\
\text { vaccine (TA-HPV) to treat cervical } \\
\text { intraepithelial neoplasia III. UK }\end{array}$ & $\begin{array}{l}\text { Cervical intraeptihelial } \\
\text { carcinoma III. } \\
\text { Phase I }\end{array}$ & $\begin{array}{l}\text { Closed } \\
\text { 1996-ND }\end{array}$ & $\begin{array}{l}\text { - HPV E6 and } \\
\text { E7 oncogenes }\end{array}$ & Vaccinia virus/ND & In vivo \\
\hline UK-0047 & $\begin{array}{l}\text { Use of a recombinant Vaccinia } \\
\text { vaccine (TA-HPV) to treat cervical } \\
\text { intraepithelial neoplasia III. UK }\end{array}$ & $\begin{array}{l}\text { Cervical intraeptihelial } \\
\text { carcinoma III. } \\
\text { Phase I }\end{array}$ & $\begin{array}{l}\text { Closed } \\
\text { 1998-ND }\end{array}$ & $\begin{array}{l}\text { - HPV E6 and } \\
\text { E7 oncogenes }\end{array}$ & Vaccinia virus/ND & In vivo \\
\hline
\end{tabular}


Table 2 (Continued)

\begin{tabular}{|c|c|c|c|c|c|c|}
\hline ID trial & Title/Country & $\begin{array}{l}\text { Indication/ } \\
\text { clinical phase }\end{array}$ & $\begin{array}{l}\text { Status/year } \\
\text { approved- } \\
\text { initiated }\end{array}$ & $\begin{array}{l}\text { Gene(s) } \\
\text { transferred }\end{array}$ & $\begin{array}{l}\text { Vector used/ } \\
\text { administration } \\
\text { route }\end{array}$ & $\begin{array}{l}\text { Gene } \\
\text { delivery }\end{array}$ \\
\hline UK-007I & $\begin{array}{l}\text { A Phase II, multi-center, double- } \\
\text { blind, placebo-controlled, dose } \\
\text { finding study of ZYCIOIa in the } \\
\text { treatment of high-grade squamous } \\
\text { intra-epithelial lesions of the } \\
\text { uterine cervix. UK }\end{array}$ & $\begin{array}{l}\text { Ano-genital } \\
\text { neoplasia III. } \\
\text { Phase II }\end{array}$ & $\begin{array}{l}\text { Open } \\
2001-N D\end{array}$ & $\begin{array}{l}\text { - HPV E6 and } \\
\text { E7 oncogenes }\end{array}$ & $\begin{array}{l}\text { Naked plasmid } \\
\text { DNA/ND }\end{array}$ & ND \\
\hline UK-0074 & $\begin{array}{l}\text { TA-HPV recombinant vaccinia } \\
\text { virus expressing the human } \\
\text { papillomavirus I } 6 \text { and I8 E6 } \\
\text { and E7 proteins: application to } \\
\text { amend currently approved } \\
\text { protocol to add a clinical trial } \\
\text { involving prime-boost strategy } \\
\text { of TA-CIN administered in } \\
\text { association with TA-HPV in } \\
\text { high-grade ano-genital } \\
\text { intraepithelial neoplasia (AGIN) } \\
\text { patients (PB-HPV/OI). UK }\end{array}$ & $\begin{array}{l}\text { Cervical cancer. } \\
\text { Phase I }\end{array}$ & $\begin{array}{l}\text { Open } \\
2001-N D\end{array}$ & $\begin{array}{l}\text { - HPV E6 and } \\
\text { E7 oncogenes }\end{array}$ & Vaccinia virus/ND & ND \\
\hline US-0307 & $\begin{array}{l}\text { Phase I trial of immunotherapy } \\
\text { with MVA-HPV-IL2 (TG400I) in } \\
\text { women with cervical intraepithelial } \\
\text { neoplasia (CIN) Grade 3. USA }\end{array}$ & $\begin{array}{l}\text { Cervical cancer. } \\
\text { Phase I }\end{array}$ & $\begin{array}{l}\text { Closed } \\
\text { I999-ND }\end{array}$ & $\begin{array}{l}\text { - HPV E6 and } \\
\text { E7 oncogenes } \\
\text { - IL-2 }\end{array}$ & $\begin{array}{l}\text { Poxvirus/ } \\
\text { intramuscular }\end{array}$ & In vivo \\
\hline US-0309 & $\begin{array}{l}\text { Phase I trial of immunotherapy } \\
\text { with MVA-HPV-IL2 (TG400I) } \\
\text { in women with advanced cervical } \\
\text { carcinoma. USA }\end{array}$ & $\begin{array}{l}\text { Cervical cancer. } \\
\text { Phase I }\end{array}$ & $\begin{array}{l}\text { Closed } \\
\text { 1999-ND }\end{array}$ & $\begin{array}{l}\text { - HPV E6 and } \\
\text { E7 oncogenes } \\
\text { - IL-2 }\end{array}$ & $\begin{array}{l}\text { Poxvirus/ } \\
\text { intramuscular }\end{array}$ & In vivo \\
\hline US-0592 & $\begin{array}{l}\text { A phase I study to determine } \\
\text { the safety and immunogenicity of } \\
\text { vaccination with Listeria } \\
\text { monocytogenes expressing HPV } \\
\text { type I } 6 \text { E7 for the treatment of } \\
\text { progressive, recurrent, and } \\
\text { advanced squamous cell cancer } \\
\text { of the cervix. USA }\end{array}$ & $\begin{array}{l}\text { Cervical cancer. } \\
\text { Phase I }\end{array}$ & $\begin{array}{l}\text { Open } \\
\text { 2003-ND }\end{array}$ & $\begin{array}{l}\text { - HPV E7 } \\
\text { oncogene }\end{array}$ & $\begin{array}{l}\text { Listeria } \\
\text { monocytogenes/ } \\
\text { intravenous }\end{array}$ & In vivo \\
\hline US-0595 & $\begin{array}{l}\text { A Phase I/II clinical trial of } \\
\text { pNGVL4a-Sig/E7 (detox)/HSP70 } \\
\text { for the treatment of patients with } \\
\text { HPVI6+ cervical intraepithelial } \\
\text { neoplasia } 2 / 3 \text { (CIN2/3). USA }\end{array}$ & $\begin{array}{l}\text { Cervical cancer. } \\
\text { Phase I and II }\end{array}$ & $\begin{array}{l}\text { Open } \\
\text { 2003-ND }\end{array}$ & $\begin{array}{l}\text { - HPVI6 } \\
\text { E7 oncogene }\end{array}$ & $\begin{array}{l}\text { Naked plasmid } \\
\text { DNA/intramuscular }\end{array}$ & In vivo \\
\hline US-0916 & $\begin{array}{l}\text { Phase I, open-label, dose escalation } \\
\text { study to evaluate the safety, } \\
\text { tolerability, and immunogenicity } \\
\text { of HPV DNA plasmid } \\
\text { (VGX-3I00) + electroporation } \\
\text { (EP) in adult females with } \\
\text { histological diagnosis of } \\
\text { grade } 2 \text { or } 3 \text { cervical intraepithelial } \\
\text { neoplasia (CIN). USA }\end{array}$ & $\begin{array}{l}\text { Cervical cancer. } \\
\text { Phase I }\end{array}$ & $\begin{array}{l}\text { Open } \\
\text { 2008-ND }\end{array}$ & $\begin{array}{l}\text { - HPVI6 E6 and } \\
\text { E7 oncogenes } \\
\text { - HPVI8 E6 and } \\
\text { E7 oncogenes }\end{array}$ & $\begin{array}{l}\text { Naked plasmid } \\
\text { DNA/intramuscular }\end{array}$ & In vivo \\
\hline US-0928 & $\begin{array}{l}\text { A Phase I efficacy and safety study } \\
\text { of HPVI6-specific therapeutic } \\
\text { DNA-rVaccinia vaccination in } \\
\text { combination with topical imiquimod } \\
\text { in patients with HPVI6+ high-grade } \\
\text { cervical dysplasia (CIN3). USA }\end{array}$ & $\begin{array}{l}\text { HPVI6+ high grade } \\
\text { cervical dysplasia. } \\
\text { Phase I }\end{array}$ & $\begin{array}{l}\text { Open } \\
\text { 2008-ND }\end{array}$ & $\begin{array}{l}\text { - HPVI6 + HPVI8 } \\
\text { - E6 + E7 oncogenes }\end{array}$ & $\begin{array}{l}\text { Naked plasmid } \\
\text { DNA + vaccinia } \\
\text { virus/intramuscular }\end{array}$ & In vivo \\
\hline
\end{tabular}


Table 2 (Continued)

\begin{tabular}{|c|c|c|c|c|c|c|}
\hline ID trial & Title/Country & $\begin{array}{l}\text { Indication/ } \\
\text { clinical phase }\end{array}$ & $\begin{array}{l}\text { Status/year } \\
\text { approved- } \\
\text { initiated }\end{array}$ & $\begin{array}{l}\text { Gene(s) } \\
\text { transferred }\end{array}$ & $\begin{array}{l}\text { Vector used/ } \\
\text { administration } \\
\text { route }\end{array}$ & $\begin{array}{l}\text { Gene } \\
\text { delivery }\end{array}$ \\
\hline US-0958 & $\begin{array}{l}\text { A randomized, double-blind, } \\
\text { placebo-controlled, parallel group, } \\
\text { multi-center study of the safety } \\
\text { and response rate of } \\
3 \text { subcutaneously administered } \\
\text { doses of } 5 \times 10^{7} \text { pfu R05217790 in } \\
\text { patients with high-grade cervical } \\
\text { intraepithelial neoplasia grade } 2 \\
\text { or } 3 \text { associated with high-risk } \\
\text { HPV infection. USA }\end{array}$ & $\begin{array}{l}\text { Cervical intraepithelial } \\
\text { neoplasia (CIN). } \\
\text { Phase II }\end{array}$ & $\begin{array}{l}\text { Open } \\
\text { 2008-ND }\end{array}$ & $\begin{array}{l}\text { - HPV E6 and } \\
\text { E7 oncogenes } \\
\text { - IL-2 }\end{array}$ & $\begin{array}{l}\text { Vaccinia virus/ } \\
\text { intramuscular }\end{array}$ & In vivo \\
\hline US-0984 & $\begin{array}{l}\text { A pilot study of pNGVL4a-CRT/ } \\
\text { E7(detox) for the treatment of } \\
\text { patients with HPVI6+ cervical } \\
\text { intraepithelial neoplasia } 2 / 3 \\
(\text { CIN2/3). USA }\end{array}$ & $\begin{array}{l}\text { Cervical cancer. } \\
\text { Phase I/II }\end{array}$ & $\begin{array}{l}\text { Open } \\
\text { 2009-ND }\end{array}$ & $\begin{array}{l}\text { - HPVI6 } \\
\text { E7 oncogene }\end{array}$ & $\begin{array}{l}\text { Naked plasmid } \\
\text { DNA/intramuscular }\end{array}$ & In vivo \\
\hline US-1040 & $\begin{array}{l}\text { Phase I, open-label study to } \\
\text { evaluate the safety, tolerability, } \\
\text { and immunogenicity of a 4th dose } \\
\text { of HPV DNA plasmid (VGX-3100) + } \\
\text { electroporation (EP) in adult } \\
\text { females previously immunized } \\
\text { with VGX-3100. USA }\end{array}$ & $\begin{array}{l}\text { Cervical cancer. } \\
\text { Phase I }\end{array}$ & $\begin{array}{l}\text { Open } \\
2010-N D\end{array}$ & $\begin{array}{l}\text { - HPVI6 E6 and } \\
\text { E7 oncogenes } \\
\text { - HPVI8 E6 and } \\
\text { E7 oncogenes }\end{array}$ & $\begin{array}{l}\text { Naked plasmid } \\
\text { DNA/intramuscular }\end{array}$ & In vivo \\
\hline US-1082 & $\begin{array}{l}\text { A Phase II evaluation of } \\
\text { ADXSII-00I (NSC } \# 7527 \text { I8, } \\
\text { IND \# I3,7I 2) in the treatment } \\
\text { of persistent or recurrent } \\
\text { squamous or on-squamous cell } \\
\text { carcinoma of the cervix. USA }\end{array}$ & $\begin{array}{l}\text { Cervical cancer. } \\
\text { Phase II }\end{array}$ & $\begin{array}{l}\text { Open } \\
2010-N D\end{array}$ & $\begin{array}{l}\text { - HPV E7 } \\
\text { oncogene }\end{array}$ & $\begin{array}{l}\text { Listeria } \\
\text { monocytogenes/ } \\
\text { intravenous }\end{array}$ & In vivo \\
\hline US-1093 & $\begin{array}{l}\text { Phase II placebo-controlled study } \\
\text { of VGX-3I00, (HPVI6 E6/E7, } \\
\text { HPVI8 E6/E7 DNA vaccine) } \\
\text { delivered IM followed by } \\
\text { electroporation (EP) with } \\
\text { cellectra-5p for the treatment of } \\
\text { biopsy-proven CIN } 2 / 3 \text { or CIN } 3 \\
\text { with documented HPV I6 or } 18 . \\
\text { USA }\end{array}$ & $\begin{array}{l}\text { Cervical cancer. } \\
\text { Phase II }\end{array}$ & $\begin{array}{l}\text { Open } \\
2011-N D\end{array}$ & $\begin{array}{l}\text { - HPVI6 E6-E7 } \\
\text { fusion protein } \\
\text { - HPVI8 E6-E7 } \\
\text { fusion protein }\end{array}$ & $\begin{array}{l}\text { Naked plasmid } \\
\text { DNA/intramuscular }\end{array}$ & In vivo \\
\hline$X X-0006$ & $\begin{array}{l}\text { Gene therapy in patients with } \\
\text { stage I cervical carcinoma. } \\
\text { Multi-country }\end{array}$ & $\begin{array}{l}\text { Stage I cervical } \\
\text { carcinoma. } \\
\text { Phase I }\end{array}$ & $\begin{array}{l}\text { Closed } \\
1999-2002\end{array}$ & $\begin{array}{l}\text { - HPV } \\
\text { - IL-2 }\end{array}$ & $\begin{array}{l}\text { Vaccinia virus/ } \\
\text { intramuscular }\end{array}$ & ND \\
\hline$X X-0007$ & $\begin{array}{l}\text { Gene therapy in patients with } \\
\text { advanced cervical carcinoma. } \\
\text { Multi-country }\end{array}$ & $\begin{array}{l}\text { Advanced cervical } \\
\text { carcinoma. } \\
\text { Phase I }\end{array}$ & $\begin{array}{l}\text { Closed } \\
1999-2002\end{array}$ & $\begin{array}{l}\text { - HPV } \\
\text { - IL-2 }\end{array}$ & $\begin{array}{l}\text { Vaccinia virus/ } \\
\text { intramuscular }\end{array}$ & ND \\
\hline
\end{tabular}

Note: Copyright @ 2012 , John Wiley and Sons. Adapted with permission from ABEDIA [webpage on the Internet]. Database of clinical trials [updated Jun 20I2]. Available from: http://www.abedia.com/wiley/index.html. Accessed August I, 2012.67

Abbreviations: HPV, human papillovirus; ND, no data provided.

\section{Recent approaches in gene therapy against cervical cancer and HPV}

The ability to selectively silence mammalian gene expression using siRNAs is a powerful tool for the understanding and manipulation of mammalian cell biology and pathology. However, it cannot be assumed that all genes will prove equal susceptibility to siRNA. ${ }^{71}$ The siRNAs have been used to characterize gene function in mammalian cells via knock-down of a large number of genes. Another potential application of siRNAs is in gene therapy specific to cancer. siRNAs are non-coding RNAs 21-25 nucleotides in length that mimic endogenous microRNAs and can effectively inhibit the translation of target mRNAs by binding to their 3'-UTR. The process is dependent upon mRNA accessibility 
and, within the target mRNA molecule, accessibility of a short internal nucleotide sequence homologous to the siRNAs transcript. Therefore, biofunctional siRNAs must be carefully and robustly designed to produce highly efficient siRNAs that can silence specific target genes.

siRNAs can be generated by chemical synthesis or by cloning in molecular vectors. Chemically synthesized siRNAs may be transfected into mammalian cells by cationic lipofection. ${ }^{72}$ It is possible to induce silencing of gene expression with synthetic siRNAs; nevertheless, this approach has disadvantages such as the high costs of production and that several doses are sometimes required. A second method for producing siRNAs is the cloning of DNA inserts in a molecular vector that will transcribe the corresponding siRNAs. ${ }^{73}$ These vectors contain DNA inserts designed with software to generate highly efficient siRNAs which are assembled with the RNA-induced silencing complex (RISC) and target mRNA for degradation or inhibition of protein translation. When these molecular vectors are administered into mammalian cells, the DNA inserts are transcribed as siRNAs under the control of the RNA Pol III promoter, forming stem-loop type secondary structures which are processed by RISC and will be assembled with target mRNA.

Although many studies have described the induction of cancer cell death in vitro by administration of specific siRNAs for HPV16/18 E6 and E7 oncogenes in cervical cancer cells, few protocols have been complemented with animal tumor models with demonstrated eradication of tumors. ${ }^{74-76}$ This is a necessary prerequisite of the in vivo evaluation, before siRNA technology can be used in clinical studies in humans. Another aspect that needs to be analyzed in depth is the ability to apply certain doses and the efficiency of siRNAs for a particular tumor. Although the first studies of siRNA against cervical cancer used chemically synthesized siRNAs, ${ }^{74}$ subsequent reports have used other molecular vectors to induce transcription of bioactive siRNAs with suppressive effects on tumor evolution in vitro as well as in vivo. ${ }^{77,78}$ With the use of molecular vectors, the expression of HPV oncogenes was inhibited in a more efficient manner. The specific delivery of siRNAs is still a limiting condition in the different models under study. However, the use of adhesive biogels, combined with liposomes and chemotherapeutic drugs, shows promise, providing a greater efficiency in the release and dosage of siRNAs at the tumor site. ${ }^{79}$

\section{Conclusion and perspectives}

Although early-stage cervical cancers have a good prognosis with a 5-year survival rate greater than $80 \%$, clinical and epidemiological evidence suggests that the natural history of HPV in young women (aged $<30$ years) may be such that establishment of a high-grade CIN lesion occurs early in the course (within 2 years) of a high-risk HPV infection. Consequences of HPV infection will depend on the infecting HPV type and site of infection, as well as on host factors that regulate virus persistence, regression, and latency. Thus, identification and subsequent functional evaluation of host proteins associated with HPV E6 and E7 oncoproteins is a major challenge for their utilization as molecular biomarkers, and may provide useful information in understanding cervical carcinogenesis for developing specific targeting strategies against tumor cells. Consequently, many experimental HPV vaccine strategies in preclinical and clinical trials are being developed in combination with immunotherapy and chemotherapy approaches for the control of HPV-associated cervical lesions.

With regard to siRNAs, the relevance of silencing the expression of HPV E6 and E7 oncogenes will be better appreciated once such strategies are applied in clinical protocols. This goal will require adequate analysis and design of siRNA sequences to induce silencing of E6-E7 bicistron, adequate selection of cloning vectors for siRNAs, selection of molecular transport vehicles for siRNAs to protect them from the action of endonucleases, and to administer them in a site-specific and dose-dependent manner, as well as in the design of treatment schemes like chemotherapy, radiotherapy, or immunotherapy, to be used in combination with siRNAs. Thus, the use of siRNA technology is a powerful gene therapy strategy against the development of cervical cancer.

In conclusion, educational strategies and organized screening programs to detect HPV infection must be implemented together with the development of therapeutic vaccines if a reduction of cervical cancer is to be achieved within the next few years. These approaches would represent a major step in reducing morbidity, but more work is required to achieve clinical efficacy at a level that can challenge current therapy. Considering that total health care costs associated with the screening and treatment of cervical cancer in the US are estimated to be US\$6 billion per year, ${ }^{80}$ it is important to take into consideration the following: the cost of each treatment; the economy and public health politics of each region, which is very relevant for the government budgeting and the technology that a country has to offer a treatment to the patients, without failing to remember that education of society is very important for the prevention and treatment of cervical cancer. 


\section{Disclosure}

The authors report no conflicts of interest in this work.

\section{References}

1. WHO/ICO Information Centre on HPV and Cervical Cancer (HPV Information Centre). Human Papillomavirus and Related Cancers in World. Summary Report 2010. WHO/ICO. 2010; November 15:1-68. http://www.who.int/hpvcentre. Accessed on July 31, 2012.

2. zur Hausen H. Papillomaviruses-to vaccination and beyond. Biochemistry (Mosc). 2008;73(5):498-503.

3. de Sanjose S, Quint WG, Alemany L, et al; Retrospective International Survey and HPC Time Trends Study Group. Human papillomavirus genotype attribution in invasive cervical cancer: a retrospective crosssectional worldwide study. Lancet Oncol. 2010;11(11):1048-1056.

4. Doorbar J. Molecular biology of human papillomavirus infection and cervical cancer. Clin Sci. 2006;110(5):525-541.

5. Wise-Draper TM, Wells SI. Papillomavirus E6 and E7 proteins and their cellular targets. Front Biosci. 2008;13:1003-1017.

6. Moody CA, Laimins LA. Human papillomavirus oncoproteins: pathways to transformation. Nat Rev Cancer. 2010;10(8):550-560.

7. Huang CF, Monie A, Weng WH, Wu TC. DNA vaccines for cervical cancer. Am J Transl Res. 2010;2(1):75-87.

8. Saito Ramalho A, Dantas Lopes A, Talans A, et al. Molecular targets for therapeutic interventions in human papillomavirus-related cancers. Oncol Rep. 2010;24(6):1419-1426.

9. Rossbach M. Therapeutic implications of microRNAs in human cancer. J Nucleic Acids Investig. 2010;2(e3):17-22.

10. Mariani L, Venuti A. HPV vaccine: an overview of immune respose, clinical protections, and new approaches for the future. J Trans Med. 2010;8:105.

11. Gissmann L, Nieto K. The therapeutics vaccines: is it feasible? Arch Med Res. 2009;40(6):493-498.

12. Welters MJ, Kenter GG, Piersma SJ, et al. Induction of tumor-specific CD4+ and CD8+ T-cell immunity in cervical cancer patients by a human papillomavirus type 16 E6 and E7 long peptides vaccine. Clin Cancer Res. 2008;14(1):178-187.

13. Bolhassani A, Mohit E, Rafati S. Different spectra of therapeutic vaccine development against HPV infections. Hum Vaccin. 2009;5(10): 671-689.

14. Ma B, Xu Y, Hung CF, et al. HPV and therapeutic vaccines: Where we are in 2010? Curr Cancer Ther Rev. 2010;6:81-103.

15. Wang S, Konorev EA, Kotamraju S, Joseph J, Kalivendi S, Kalyanaraman B. Doxorubicin induces apoptosis in normal and tumor cells via distinctly different mechanisms intermediacy of $\mathrm{H}(2)$ O(2)- and p53-dependent pathways. J Biol Chem. 2004;279(24): 25535-25543.

16. Mielgo A, Torres VA, Clair K, Barbero S, Stupack DG. Paclitaxel promotes a caspase 8-mediated apoptosis through death effector domain association with microtubules. Oncogene. 2009;28(40): 3551-3562.

17. Casares N, Pequignot MO, Tesniere A, et al. Caspase-dependent immunogenicity of doxorubicin-induced tumor cell death. J Exp Med. 2005;202(12):1691-1701.

18. Panaretakis T, Kepp O, Brockmeier U, et al. Mechanisms of preapoptotic calreticulin exposure in immunogenic cell death. EMBO J. 2009;28:578-590.

19. Michaud M, Martins I, Sukkurwala AQ, et al. Autophagy-dependent anticancer immune responses induced by chemotherapeutic agents. Science. 2012;334:1573-1577.

20. Apetoh L, Ghiringhelli F, Tesniere A, et al. The interaction between HMGB1 and TLR4 dictates the outcome of anticancer chemotherapy and radiotherapy. Immunol Rev. 2007;220:47-59.

21. Srivastava P. Roles of heat-shock proteins in innate and adaptive immunity. Nat Rev Immunol. 2002;2:185-194.
22. Miller RL, Meng TC, Tomai MA. The antiviral activity of Toll-like receptor 7 and 7/8 agonists. Drug News Perspect. 2008;21:69-87.

23. Bilu D, Sauder DN. Imiquimod: modes of action. Br J Dermatol. 2003: 149:5-8.

24. Van Seters M, van Beurden M, ten Kate FJ, et al. Treatment of vulvar intraepithelial neoplasia with topical imiquimod. N Engl J Med. 2008; 358:1465-1475.

25. Daayana S, Ekord E, Winters U, et al. Phase II trial of imiquimod and HPV therapeutic vaccination in patients with vulva intraepithelial neoplasia. Br J Cancer. 2010;102:1129-1136.

26. Chuang CM, Monei A, Hung CH, Wu TC. Treatment with imiqimod enhances antitumor immunity induced by therapeutic HPV DNA vaccination. J Bio Sci. 2010;17:32-40.

27. Suzuki E, Sun J, Kapoor V, Jassar As, Albelda SM. Gemcitabine has significant immunomodulatory activity in murine models independent of its cytotoxic effects. Cancer Biol Ther. 2007;6:880-885.

28. Lui WM, Fowler DW, Smith P, Dalgleish AG. Pre-treatment with chemotherapy can enhance the antigenicity and immunogenicity of tumours by promoting adaptive immune responses. Br J Cancer. 2010; 102:115-123.

29. Machado FA, Janssens JP, Michelin MA, Murta EF. Immune response and immunotherapy in intraepithelial and invasive lesions of the uterine cervix. Clin Exp Obstet Gynecol. 2012;39(1):27-31.

30. Bermúdez-Morales VH, Peralta-Zaragoza O, Madrid-Marina V. Gene therapy with cytokines against cervical cancer. Salud Publica Mex. 2005;47(6):458-468.

31. Leachman SA, Tigelarr M, Shlyankevich M, et al. Granulocytemacrophage colony-stimulating factor priming plus papillomavirus E6 DNA vaccination: effects on papilloma formation and regression in the cottontail rabbit papillomavirus-rabbit model. J Virol. 2000;74: 8700-8708.

32. Colombo MP, Trinchieri G. Interleukin-12 in anti-tumor immunity and immunotherapy. Cytokine Growth Factor Rev. 2002;13:155-168.

33. Indrová M, Bieblová J, Rossowska J, et al. HPV 16-associated tumours: IL-12 can repair the absence of cytotoxic and proliferative responses of tumour infiltrating cells after chemotherapy. Int J Oncol. 2009;34(1): 173-179.

34. Lui VW, He Y, Falo L, Huang L. Systemic administration of naked DNA encoding interleukin 12 for the treatment of human papillomavirus DNA-positive tumor. Hum Gene Ther. 2002;13:177-185.

35. Ahn WS, Bae SM, Kim TY, et al. A therapy modality using recombinant IL-12 adenovirus plus E7 protein in a human papillomavirus 16 E6/ E7-associated cervical cancer animal model. Hum Gene Ther. 2003; 14(15):1389-1399.

36. Indrová M, Bubenik J, Mikyskova R, et al. Chemoimmunotherapy in mice carrying HPV16-associated, MHC class I+ and class I tumours: Effects of CBM-4 A potentiated with IL-2, IL-12, GM-CSF and genetically modified tumour vaccines. Int J Oncol. 2003;22: 691-695.

37. Bergot AS, Kassianos A, Frazer IH, et al. New approaches to Immunotherapy for HPV associated Cancers. Cancer. 2011;3: 3461-3495.

38. Cortes-Perez NG, Azevedo V, Alcocer-Gonzalez JM, et al. Cell surface display of E7 antigen from human papillomavirus type-16 in Lactococcus lactis and in Lactobacillus plantarum using a new cell-wall anchor from lactobacilli. J Drug Target. 2005;13(2): 89-98.

39. Sewell DA, Shahabi V, Gunn GR, et al. Recombinant Listeria vaccines containing PEST sequences are potent immune adjuvants for the tumorassociated antigen human papillomavirus-16 E7. Cancer Res. 2004; 64(24):8821-8825.

40. Echchannaoui $\mathrm{H}$, Bianchi M, Baud D, et al. Intravaginal immunization of mice with recombinant Salmonella enterica serovar Typhimurium expressing human papillomavirus type 16 antigens as a potential route of vaccination against cervical cancer. Infect Immun. 2008;76(5): 1940-1951. 
41. Hsieh CJ, Kim TW, Hung CF, et al. Enhancement of vaccinia vaccine potency by linkage of tumor antigen gene to gene encoding human papillomavirus type 16 E7 protein. Clin Vaccine Immunol. 2008;15(5): 817-824.

42. Lee DW, Anderson ME, Wu S, et al. Development of an adenoviral vaccine against E6 and E7 oncoproteins to prevent growth of human papillomavirus-positive cancer. Arch Otolaryngol Head Neck Surg. 2008;134(12):1316-1323.

43. Liao JB, Publicover J, Rose JK, et al. Single-Dose, therapeutic vaccination of mice with vesicular stomatitis virus expressing human papillomavirus type 16 E7 protein. Clin Vaccine Immunol. 2008;15(5):817-824.

44. Zhou L, Zhu T, Ye X, et al. Long-term protection against human papillomavirus E7-positive tumor by a single vaccination of adenoassociated virus vectors encoding a fusion protein of inactivated E7 of human papillomavirus 16/18 and heat shock protein 70. Hum Gene Ther. 2010;21(1):109-119.

45. Daemen T, Riezebos-Brilman A, Regts J, et al. Superior therapeutic efficacy of alphavirus-mediated immunization against human papillomavirus type 16 antigens in a murine tumour model: effects of the route of immunization. Antivir Ther. 2004;9(5):733-742.

46. Davidson EJ, Faulkner RL, Sehr P, et al. Effect of TA-CIN (HPV 16 L2E6E7) booster immunization in vulval intraepithelial neoplasia patients previously vaccinated with TA-HPV (vaccinia virus encoding HPV 16/18 E6E7). Vaccine. 2004;22(21-22):2722-2729.

47. Baldwin PJ, van der Burg SH, Boswel CM, et al. Vaccinia expressed human papillomavirus 16 and $18 \mathrm{E} 6$ and E7 as a therapeutic vaccination for vulval and vaginal intraepithelial neoplasia. Clin Cancer Res. 2003;9(14):5205-5213.

48. Corona-Gutierrez CM, Tinoco A, Navarro T, et al. Therapeutic vaccination with MVA E2 can eliminate precancerous lesions (CIN 1, CIN 2, and CIN 3) associated with infection by oncogenic human papillomavirus. Hum Gene Ther. 2004;15(5):421-431.

49. García-Hernández E, González-Sánchez JL, Andrade-Manzano A et al. Regression of papilloma high-grade lesions (CIN 2 and CIN 3) is stimulated by therapeutic vaccination with MVA E2 recombinant vaccine. Cancer Gene Ther. 2006;13(6):592-597.

50. Kenter GG, Welters MJ, Valentijin AR, et al. Vaccination against HPV-16 oncoproteins for vulva intraepithelial neoplasia. $N$ Engl J Med. 2009;361:1838-1847.

51. Vambutas A, DeVoti J, Nouri M, et al. Therapeutic vaccination with papillomavirus E6 and E7 long peptides results in the control of both established virus-induced lesions and latently infected sites in a preclinical cottontail rabbit papillomavirus model. Vaccine. 2005;23(45): 5271-5280.

52. Chen W, Huang L. Induction of cytotoxic T-lymphocytes and antitumor activity by a liposomal lipopeptide vaccine. Mol Pharm. 2008;5(3): 464-471.

53. Sharma RK, Elpek KG, Yolcu ES, et al. Costimulation as a platform for the development of vaccines: a peptide-based vaccine containing a novel form of 4-1BB ligand eradicates established tumors. Cancer Res. 2009;69(10):4319-4926.

54. Kim TG, Kim CH, Won EH, et al. CpG-ODN-stimulated dendritic cells act as a potent adjuvant for $\mathrm{E} 7$ protein delivery to induce antigen-specific antitumour immunity in a HPV 16 E7-associated animal tumour model. Immunology. 2004;112(1):117-125.

55. Cui Z, Huang L. Liposome-polycation-DNA (LPD) particle as a carrier and adjuvant for protein-based vaccines: therapeutic effect against cervical cancer. Cancer Immunol Immunother. 2005;54(12):1180-1190.

56. Frazer IH, Quinn M, Nicklin JL, et al. Phase 1study of HPV16-specific immunotherapy with E6E7 fusion protein and Iscomatrix adjuvant in women with cervical intraepithelial neoplasia. Vaccine. 2004;23(2): $172-181$

57. Liao CW, Chen CA, Lee CN, et al. Fusion protein vaccine by domains of bacterial exotoxin linked with a tumor antigen generates potent immunologic responses and antitumor effects. Cancer Res. 2005; 65(19):9089-9098.
58. Hung CF, Calizo R, Tsai YC, He L, Wu TC. A DNA vaccine encoding a single-chain trimer of HLA-A2 linked to human mesothelin peptide generates anti-tumor effects against human mesothelin-expressing tumors. Vaccine. 2007;25(1):127-135.

59. Lu D, Hoory T, Monie A, Wu A, Wang MC, Hung CF. Treatment with demethylating agent, 5-aza-2'-deoxycytidine enhances therapeutic HPV DNA vaccine potency. Vaccine. 2009;27(32):4363-4369.

60. Kim D, Hoory T, Monie A, Ting JP, Hung CF, Wu TC. Enhancement of DNA vaccine potency through coadministration of CIITA DNA with DNA vaccines via gene gun. J Immunol. 2008;180(10): 7019-7027.

61. Huang CH, Peng S, He L, et al. Cancer immunotherapy using a DNA vaccine encoding a single-chain trimer of MHC class I linked to an HPV-16 E6 immunodominant CTL epitope. Gene Ther. 2005;12(15): 1180-1186.

62. Martinon F, Brochard P, Ripaux M, et al. Improved protection against simian immunodeficiency virus mucosal challenge in macaques primed with a DNA vaccine and boosted with the recombinant modified vaccinia virus Ankara and recombinant Semliki Forest virus. Vaccine. 2008;26(4):532-545.

63. Cheng WF, Hung CF, Hsu KF, et al. Cancer immunotherapy using Sindbis virus replicon particles encoding a VP22-antigen fusion. Hum Gene Ther. 2002;13(4):553-568.

64. Mikysková R, Indrová M, Símová J, et al. Treatment of minimal residual disease after surgery or chemotherapy in mice carrying HPV16associated tumours: Cytokine and gene therapy with IL-2 and GM-CSF. Int J Oncol. 2004;24(1):161-167.

65. Kim JH, Kang TH, Noh KH, et al. Enhancement of dendritic cell-based vaccine potency by anti-apoptotic siRNAs targeting key pro-apoptotic proteins in cytotoxic CD8(+) T cell-mediated cell death. Immunol Lett. 2009;122(1):58-67.

66. Santin AD, Bellone S, Palmieri M, et al. Human papillomavirus type 16 and 18 E7-pulsed dendritic cell vaccination of stage IB or IIA cervical cancer patients: A phase I escalating-dose trial. J Virol. 2008;82(4): 1968-1979.

67. ABEDIA [webpage on the Internet]. Database of clinical trials [updated Jun 2012]. Available from: http://www.abedia.com/wiley/index.html. Accessed August 1, 2012.

68. US National Institutes of Health [website] Database of clinical trials. [Updated July 30, 2012]. Available from: http://clinicaltrials.gov/ct2/ home. Accessed on August 8, 2012.

69. Adams M, Borysiewicz L, Fiander A, et al. Clinical studies of human papilloma vaccines in pre-invasive and invasive cancer. Vaccine. 2001;19(17-19):2549-2556.

70. Sima N, Wang S, Wang W, et al. Antisense targeting human papillomavirus type 16 E6 and E7 genes contributes to apoptosis and senescence in SiHa cervical carcinoma cells. Gynecol Oncol. 2007; 106(2):299-304

71. Liu Z, Sall A, Yang D. MicroRNA: an emerging therapeutic target and intervention tool. Int J Mol Sci. 2008;9:978-999.

72. Sioud M, Sorensen DR. Cationic liposome-mediated delivery of siRNAs in adult mice. Biochem Biophys Res Commun. 2003;312: 1220-1225.

73. Brummelkamp TR, Bernards R, Agami R. A system for stable expression of short interfering RNAs in mammalian cells. Science. 2002;296:550-553.

74. Jiang M, Milner J. Selective silencing of viral gene expression in HPVpositive human cervical carcinoma cells treated with siRNA, a primer of RNA interference. Oncogene. 2002;21:6041-6048.

75. Niu XY, Peng ZL, Duan WQ, Wang H, Wang P. Inhibition of HPV 16 E6 oncogene expression by RNA interference in vitro and in vivo. Int J Gynecol Cancer. 2006;16:743-751.

76. Salazar-León J, Reyes-Román F, Meneses-Acosta A, et al. Silencing of HPV16 E6 and E7 oncogenic activities by small interference RNA induces autophagy and apoptosis in human cervical cancer cells. J Nucleic Acids Investig. 2011;2:e10:59-69. 
77. Chang JT, Kuo TF, Chen YJ, et al. Highly potent and specific siRNAs against E6 or E7 genes of HPV16- or HPV18-infected cervical cancers. Cancer Gene Ther. 2010;17(12):827-836.

78. Takuma F, Miyuki S, Eri I, et al. Intratumor injection of small interfering RNA-targeting human papillomavirus 18 E6 and E7 successfully inhibits the growth of cervical cancer. Int J Oncology. 2006;29: $541-548$.
79. Wu SY, Singhania A, Burgess M, et al. Systemic delivery of E6/7 siRNA using novel lipidic particles and its application with cisplatin in cervical cancer mouse models. Gene Ther. 2011;18(1):14-22.

80. Mahdavi A, Monk BJ. Vaccines against human papillomavirus and cervical cancer: Promises and challenges. Oncologist. 2005;10: $528-538$.

\section{Publish your work in this journal}

OncoTargets and Therapy is an international, peer-reviewed, open access journal focusing on the pathological basis of all cancers, potential targets for therapy and treatment protocols employed to improve the management of cancer patients. The journal also focuses on the impact of management programs and new therapeutic agents and protocols on

\section{Dovepress}

patient perspectives such as quality of life, adherence and satisfaction. The manuscript management system is completely online and includes a very quick and fair peer-review system, which is all easy to use. Visit http://www.dovepress.com/testimonials.php to read real quotes from published authors.

\footnotetext{
Submit your manuscript here: http://www.dovepress.com/oncotargets-and-therapy-journal
} 